\title{
AN EXPERIMENTAL STUDY ON SANDWICH COMPOSITE PANEL INFILLED STEEL FRAMES
}

\author{
Hetao Hou ${ }^{1,2,3^{*}}$, Canxing Qiu ${ }^{1}$, Jingfeng Wang ${ }^{4}$ and GuoQiang $\mathrm{Li}^{3}$ \\ ${ }^{1}$ Associate Professor, School of Civil Engineering, Shandong University, Jinan, China \\ ${ }^{2}$ Postdoctor, Laiwu Steel Group Limited, Laiwu, Shandong, China \\ ${ }^{3}$ Professor, School of Civil Engineering, Tongji University, Shanghai, China \\ ${ }^{4}$ Associate Professor, School of Civil Engineering, Hefei University of Technology, Hefei, China \\ *(Corresponding author: E-mail: houhetao@163.com)
}

Received: 31 May 2011; Revised: 28 August 2011; Accepted: 23 September 2011

\begin{abstract}
Cyclic loading tests on eight full-scale one storey, one-bay test specimens were carried out to study the hysteretic behavior of steel frames infilled with sandwich composite panels. Six main influential parameters, including panel thickness, panel type, panel position, column orientation, beam-to-column connection type and connecting method of panel to steel frame are considered. Based on the experimental phenomena, seismic behaviors of specimens were reflected by hysterics loops, skeleton curves, curves of strength degradation, curves of stiffness degradation, ductility coefficient and equivalent damping coefficient. Test results show that the failure modes of panels and steel frames are concrete spalling around the embedded parts, weld fracture, and local buckling of beam, respectively. The integrity of the panel is better than the traditional walls. The success of connection between panel and steel frame is significant to the mutual work of the two parts. Both of increasing the panel thickness and strengthening the connection can improve the seismic behavior of structure. At the end of the paper, seismic design recommendations based on the analysis of ductility index and energy dissipation of the structures are presented.
\end{abstract}

Keywords: Composite panels, Steel frames, Hysteretic behavior, Low cyclic loading tests

\section{INTRODUCTION}

Generally, the infilled walls in frame structures are intended to serve as internal partitions or external claddings. Therefore, the structures are always designed without taking account of the infilled walls in the overall behavior of the building. Nevertheless, although infilled walls are considered as non-structural parts in a frame, they have been widely recognized that the existence of infills within the interior of the buildings considerably improve their lateral stiffness, ultimate strength and energy dissipation capacity against earthquakes. In many cases of infilled frames with traditional walls made of concrete or bricks, much research have been carried out for analysis and design of these infilled frames when subjected to in-plane forces.

Polyakov [1,2] carried out parameter analysis of 65 large-scale infilled steel frames. The parameters included masonry units, mortar, method of loading, and wall openings. Besides individual panels, a three-story, three-bay frame of one-quarter scale was also tested. In the paper, Polyakov obtained the conclusion that the multistory-multibay infilled frame behaved as a group of individually braced frames, but not as a single monolith. The braced frame model was also confirmed by Papia et al. [3] and Cavaleri et al. [4] who defined a diagonal pin-jointed strut being able to represent the horizontal force-interstorey displacement cyclic law of the actual masonry infill. The proposed technique, unlike the previous empirical approaches, involves the axial stiffness of the columns of the frame more than their flexural stiffness. As a support of the analytical discussion, an experimental investigation involving single storey-single bay infilled reinforced concrete was carried out. The experimental results were taken into account to improve the proposed model. 
Holmes [5] suggested a simple procedure for calculating the ultimate load and lateral displacement of steel frames with brickwork or concrete infilling. In the analytical model, the wall panel was replaced by an equivalent strut, the cross sectional area of which was obtained as $t d / 3$, by assuming that the reaction between the steel frame and infilling varies linearly along the frame beam. A comparison is then made with thirteen test results. The simplified equivalent strut for concrete block masonry walls was further studied (Khalid et al. [6]). In his paper, several quasi-static experiments on infilled frames were conducted. The specimens were quarter-scale semi-rigidly connected steel frames infilled with non-integral unreinforced concrete block masonry walls. Three primary parameters were investigated, including number of bays, material properties of the concrete blocks and the mortar joint, and type of infill openings. A varied cross-sectional area of equivalent strut model was proposed and furthermore, a model for the hysteresis loop was formulated.

Other researchers (Liauw and Kwan [7,8]) studied the non-linear behavior of a pair of four-storey single-span infilled frame both experimentally and analytically. For the non-integral infilled frames, it showed that the strength of non-integral infilled frames depended on the bending strength of the frame; while for the integral infilled frames, in which the infill and the frame are bonded or connected together, the effects of the connectors were investigated in relation to the stiffness and strength of the infilled frames.

Moghadam [9] conducted an intensive research on the seismic behavior of infilled frames and the research results included many aspects, such as the crack strength determination of infilled steel frames (Moghadam et al. [10]), the impact of repair and retrofit on in-plane behavior of masonry infilled steel frames (Moghadam [11]), seismic strengthening of masonry infilled structures (Moghadam and Mahmoodi [12]), mathematical functions to evaluate stress of infilled frames (Mahmoodi and Moghadam [13]), discrete element method in the nonlinear analysis of masonry-infilled steel frames with opening (Mohammadi et al. [14]).

Saari et al. [15] reported the seismic behavior of headed shear stud connectors for use in steel frames with partially restrained connectors and reinforced concrete infill walls. An experimental program was developed to quantify the strength and deformation capacities of shear studs for use in S-RCW infill system, and several design equations were verified. The study on the headed stud connectors lead to a further research carried out by Tong et al. [16], who studied the experimental and cyclic behavior of a composite structural system consisting of partially-restrained steel frames with reinforced concrete infill walls. The study showed that the system had the potential to offer strength appropriate for resisting the forces from earthquakes and stiffness adequate for controlling drift for low- to moderate-rise buildings located in earthquake-prone regions.

Despite the large amount of the previously mentioned literatures, it is evident that limited researches (Wright and Gallocher [17], Hanaor [18], Matteis and Landolfo [19]) are concerned about the sandwich composite panels. The sandwich composite panel was used because of its advantages of high ratio of strength to weight, good fire resisting performance, and excellent heat preservation capacity. The objective of this paper is to report an experimental investigation on steel frames infilled with sandwich composite panels. 


\section{EXPERIMENTAL RESEARCH}

\subsection{Description of specimens}

In this experiment, eight specimens were manufactured and tested to investigate the performance of infilled frames under earthquake-type loading. The test frame was a full-scale one-bay, one-storey steel frame. The columns for specimen were H-shaped steel sections of a cross-section HW2 $50 \times 250 \times 9 \times 14 \mathrm{~mm}$, the beams were H-shaped steel sections of a cross-section HN250 $\times 125 \times 6 \times 9 \mathrm{~mm}$. The parameters varied in these experiments included the following: (1) panel thickness; (2) panel type; (3) panel position; (4) column orientation; (5) joint of steel frame; (6) connecting method between steel frame and panel. The characteristics of the test specimens are summarized in Table 1, with a schematic test setup shown in Figure 1. S1 was selected as reference specimen, while other specimens were designed according to the parameters. Geometrical dimensions of all specimens were selected to be the same. Properties of the test frames are shown in Figure 2. Connection between the frame and the infill was achieved by using a steel plate that was welded on the column flange, and a bolt that was drawn into the embedded part in the panel, as shown in Figure 2(a). Table 2 summarizes the results of the material tests of the steel coupons used in the specimens. The average compressive strength of concrete cubes $(150 \mathrm{~mm} \times 150 \mathrm{~mm} \times 150 \mathrm{~mm})$ was tested as $26.5 \mathrm{~N} / \mathrm{mm}^{2}$, and the elastic modulus was given as $3.1 \times 10^{4} \mathrm{~N} / \mathrm{mm}^{2}$.

Table 1. Characteristics of Specimens

\begin{tabular}{|c|c|c|c|c|c|c|}
\hline Specimen & $\begin{array}{c}\text { Panel } \\
\text { thickness } \\
(\mathrm{mm})\end{array}$ & $\begin{array}{l}\text { Panel } \\
\text { type }\end{array}$ & $\begin{array}{l}\text { Panel } \\
\text { position }\end{array}$ & $\begin{array}{l}\text { Column } \\
\text { orientation }\end{array}$ & Frame joint & $\begin{array}{l}\text { Connecting } \\
\text { method }\end{array}$ \\
\hline $\mathrm{S} 1$ & 140 & $\mathrm{SC}^{\mathrm{a}}$ & Infilled & Strong & $\begin{array}{c}\text { Welded } \\
\text { flange-Bolted web }\end{array}$ & Column \\
\hline S2 & 140 & $C L^{b}$ & Infilled & Strong & $\begin{array}{c}\text { Welded } \\
\text { flange-Bolted web }\end{array}$ & Column \\
\hline S3 & 170 & $\mathrm{SC}$ & Infilled & Strong & $\begin{array}{c}\text { Welded } \\
\text { flange-Bolted web }\end{array}$ & Column \\
\hline S4 & 140 & $\mathrm{SC}$ & Infilled & Strong & $\begin{array}{c}\text { Welded } \\
\text { flange-Bolted web }\end{array}$ & Beam \\
\hline S5 & 140 & $\mathrm{SC}$ & $\begin{array}{l}\text { Out-hang } \\
\text { ed }\end{array}$ & Strong & $\begin{array}{c}\text { Welded } \\
\text { flange-Bolted web }\end{array}$ & Column \\
\hline S6 & 140 & $\mathrm{SC}$ & Infilled & Strong & $\begin{array}{l}\text { End-plate } \\
\text { connection }\end{array}$ & Column \\
\hline S7 & 140 & $\mathrm{SC}$ & Infilled & Strong & $\begin{array}{c}\text { Welded } \\
\text { flange-Bolted web }\end{array}$ & $\begin{array}{l}\text { Column \& } \\
\text { Beam }\end{array}$ \\
\hline S8 & 140 & $\mathrm{SC}$ & Infilled & Weak & $\begin{array}{l}\text { Welded } \\
\text { flange-Bolted web }\end{array}$ & Column \\
\hline
\end{tabular}

Notes: $\mathrm{a}$-Sandwich composite panel, $\mathrm{b}$-Composite light-weight panel 
Table 2. Properties of Specimens

\begin{tabular}{cccccc}
\hline $\begin{array}{c}\text { Specimen } \\
\text { number }\end{array}$ & $\begin{array}{c}\text { Thickness } \\
(\mathrm{mm})\end{array}$ & $\begin{array}{c}\text { Yield } \\
\text { stress }\left(\mathrm{N} / \mathrm{mm}^{2}\right)\end{array}$ & $\begin{array}{c}\text { Ultimate } \\
\text { stress }\left(\mathrm{N} / \mathrm{mm}^{2}\right)\end{array}$ & $\begin{array}{c}\text { Elastic } \\
\text { modulus }\left(\mathrm{N} / \mathrm{mm}^{2}\right)\end{array}$ & $\begin{array}{c}\text { Elongation at } \\
\text { fracture (\%) }\end{array}$ \\
\hline Beam flange & 9 & 261.5 & 400.5 & $1.97 \times 10^{5}$ & 16 \\
$\begin{array}{c}\text { Beam web } \\
\text { Column }\end{array}$ & 6 & 271.3 & 430.5 & $2.05 \times 10^{5}$ & 19 \\
$\quad \begin{array}{l}\text { flange } \\
\text { Column web }\end{array}$ & 14 & 240.0 & 370.6 & $1.90 \times 10^{5}$ & 14 \\
$\begin{array}{c}\text { Connecting } \\
\text { plate }\end{array}$ & 10 & 258.6 & 390.5 & $1.97 \times 10^{5}$ & 18 \\
Endplate & 25 & 249.3 & 380.4 & $1.95 \times 10^{5}$ & 15 \\
\hline
\end{tabular}

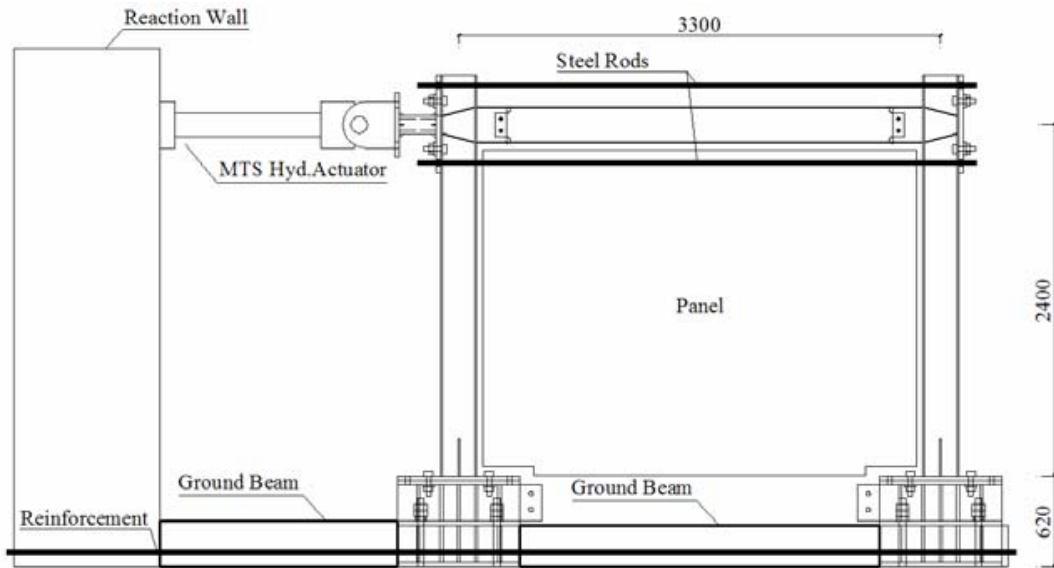

Figure 1. Test Setup (Dimensions in $\mathrm{mm}$ )

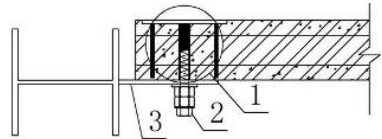

(a) Infilled

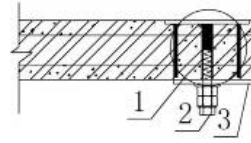

(b) Out-hanged

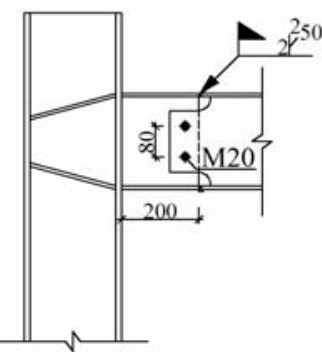

(c) Welded flange-Bolted web

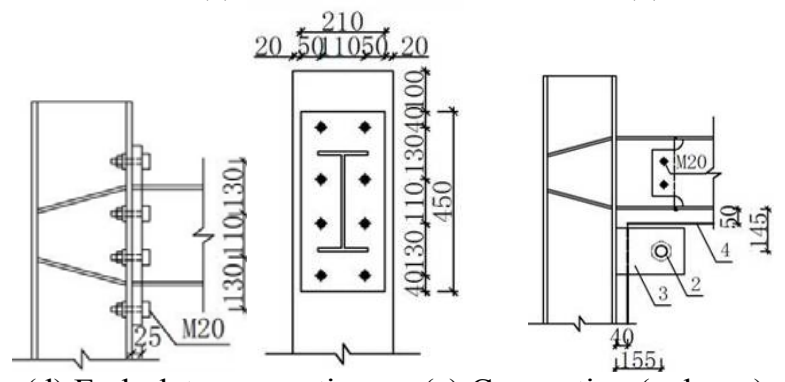

(d) End-plate connection

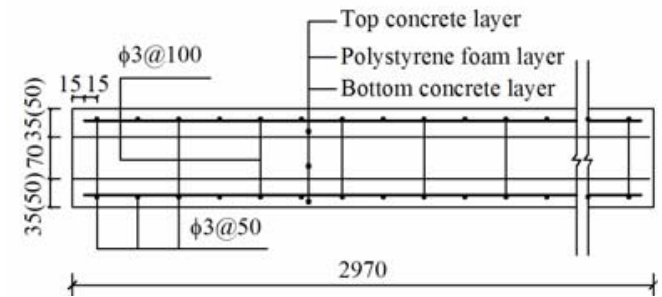

(h) Horizontal section of SC panel
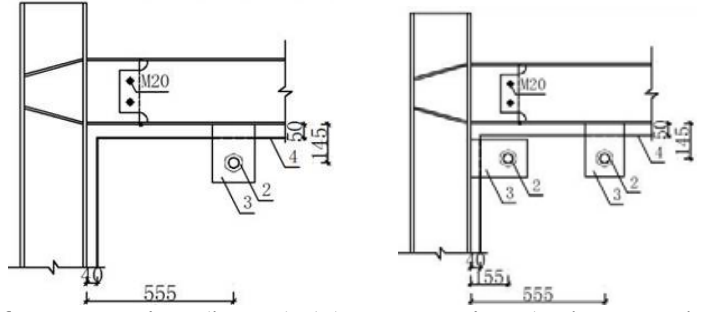

(f) Connection (beam) (g) Connection (column \& beam)

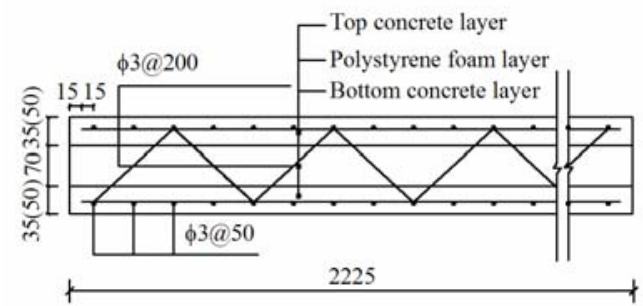

(i) Vertical section of SC panel 


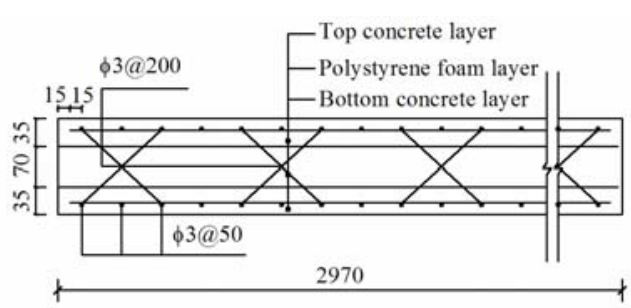

(j) Horizontal section of CL panel

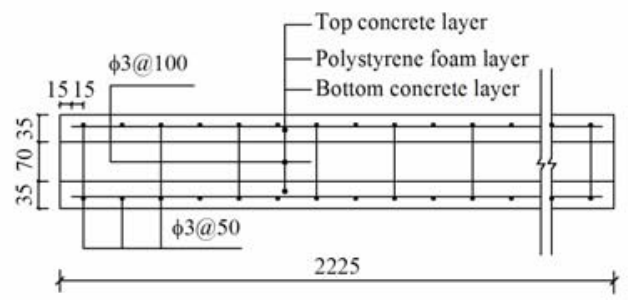

(k) Vertical section of CL panel

Figure 2. Characteristics of the Test Frames

1—Embedded part; 2-Bolt (M20); 3-Connecting plate (-220x160x10); 4-Panel edge

\subsection{Experimental Setup and Testing Procedure}

In order to investigate the effect of reversed cyclic lateral load on specimens, a closed-loop servo-hydraulic system was used to load the specimens by imposing cyclic static displacements in the plane of the wall at the center line of the beam. No axial load was applied to any of the specimens. The schematic of test setup and loading system is shown in Figure 1. The testing system consisted of reaction wall, ground beam, loading equipment and data acquisition system. The specimens were instrumented with LVDTs (linear variable differential transformers) to measure in-plane displacements and out-of-plane displacements. During the tests, story displacements and the lateral loads were monitored. After each cycle, new initiated cracks and crack propagation were marked on the specimens and failure mechanisms were observed.

The testing procedure of the experimentation, shown in Figure 3, was based on the ATC-24 [20] guidelines for cyclic testing of steel structures. The loading history was divided into two parts: elastic cycles and inelastic cycles. Firstly, the elastic cycles were imposed on the specimens by displacement control at levels of $0.25 \Delta_{y}, 0.5 \Delta_{y}$ and $0.7 \Delta_{y}$, where $\Delta_{y}$ is the evaluated lateral yielding displacement corresponding to the lateral yielding load $P_{y}$. In this paper, $\Delta_{y}$ is taken as $9.6 \mathrm{~mm}$ approximately based on the numerical analysis results. Two cycles were conducted at each of the lateral displacement of $0.25 \Delta_{y}, 0.5 \Delta_{y}$ and $0.7 \Delta_{y}$. In further cycles, the inelastic cycles were applied to lateral displacement levels of $1.0 \Delta_{y}, 1.5 \Delta_{y}, 2.0 \Delta_{y}, 3.0 \Delta_{y}, 5.0 \Delta_{y}$, and $7.0 \Delta_{y}$. Three cycles were imposed at displacement levels of $1.0 \Delta_{y}, 1.5 \Delta_{y}$, and $2.0 \Delta_{y}$; while two cycles were imposed at the other displacement levels listed above. The magnitude of the displacement increased gradually until any of the following phenomenon occurred: (1) severe local buckling of beams or columns; (2) shearing of bolts; (3) large deformation or deflection of members; (4) corner crushing of panels; (5) throughout cracks on the surface of panels.

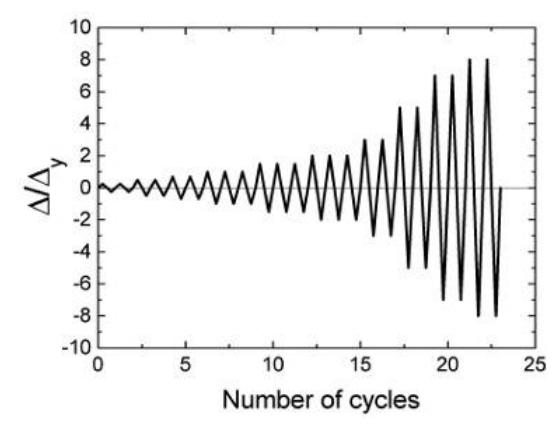

Figure 3. Testing Procedure 


\subsection{Instrumentation}

Each beam end displacement was automatically recorded by a hydraulic actuator acting on each beam end. In addition, seven linear variable displacement transducers (LVDTs) were mounted to measure the middle displacement of column and panel, slip displacement of column bottom, and side-sway of the specimens. The layout of the LVDTs is illustrated in Figure 4.

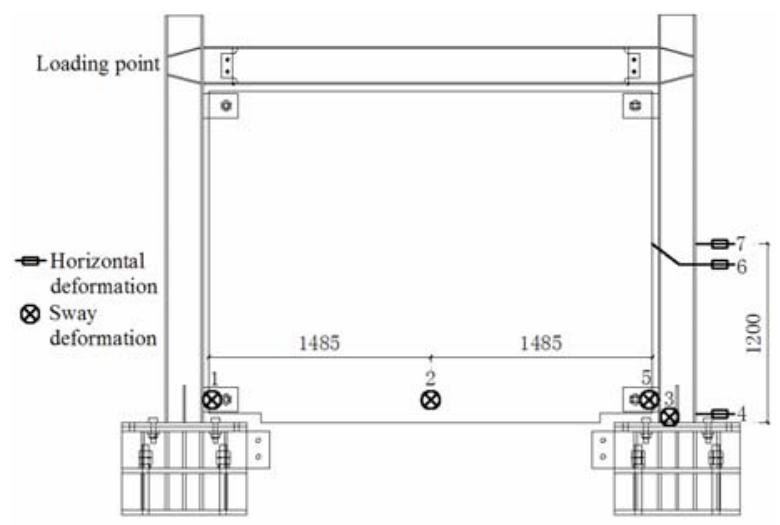

Figure 4. Layout of LVDTs (Unit: $\mathrm{mm}$ )

For the test specimens, a total of fifty-nine strain gauges were employed in each specimen excepted S6 in which six additional strain gauges were employed to measure the end plate strain. Strain gauges were used to monitor the strains in the flanges and webs of beam and column, and strain rosettes were applied to calculate the principle strain of steel connecting plate and panel. All the test results were recorded by Portable Data Collection System (Japan-TDS303). The layout of strain gauges is illustrated in Figure 5.

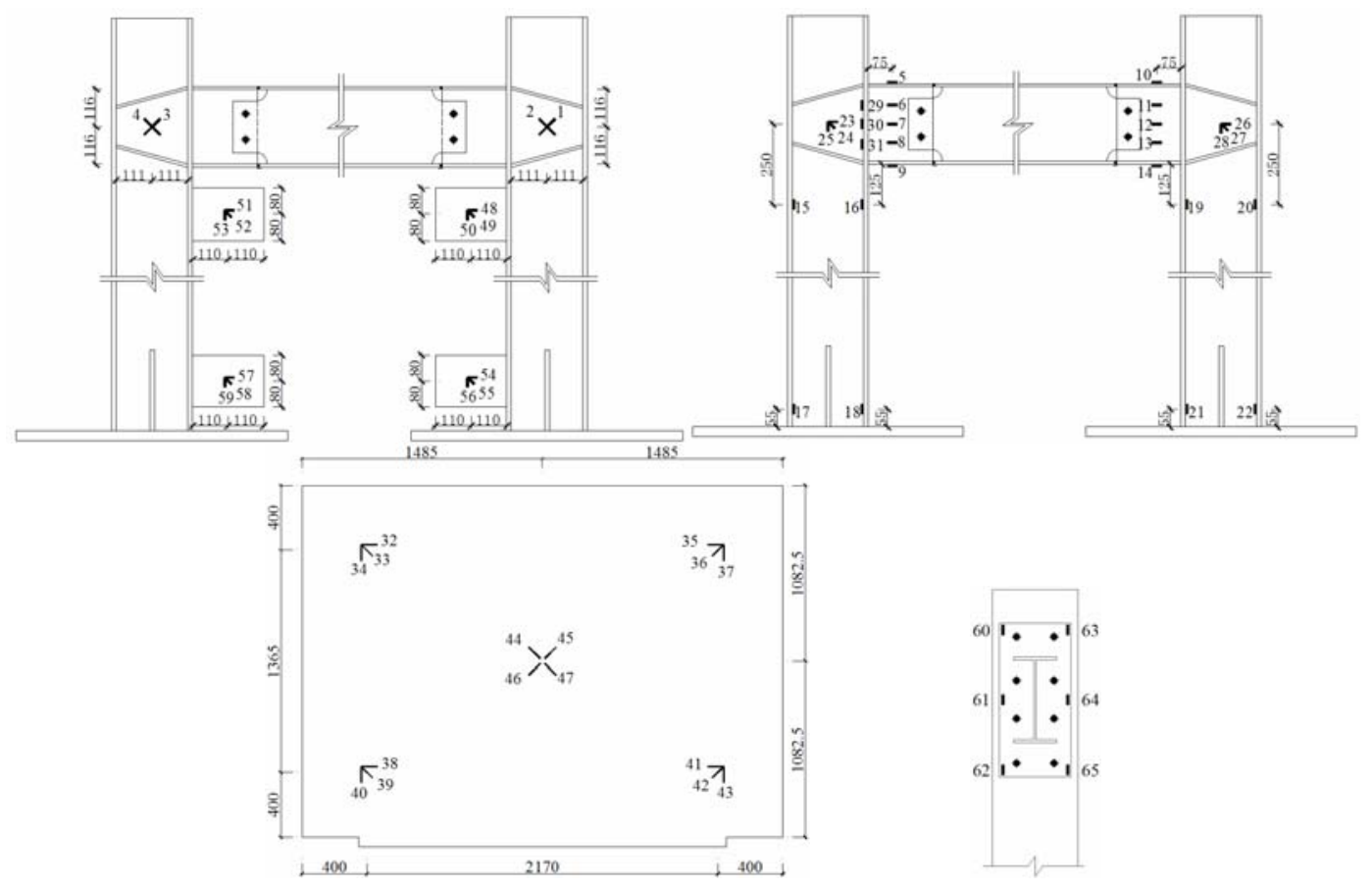

Figure 5. Layout of Strain Gauges (Unit:mm) 


\section{EXPERIMENTAL RESULTS}

\subsection{Failure modes}

The main experimental procedure of S1 subjected to cyclic displacement load is described below: when the displacement of beam end reached $1.6 \mathrm{~mm}$ at the first cycle of $0.5 \Delta_{y}$, short small cracks appeared on the panel surface around the right-bottom and left-top embedded parts; when the displacement reached $-2.4 \mathrm{~mm}$ at the second cycle, a $25 \mathrm{~cm}$ long vertical small crack was found in the middle part of panel surface. During the loading cycle of $2.0 \Delta_{y}$, with the displacement increased to $-9.6 \mathrm{~mm}$ at the first cycle, the crack in the middle part of panel surface propagated to the top; meanwhile some $15 \mathrm{~cm}$ long cracks appeared on the panel surface around the left-bottom and right-bottom embedded parts, when the displacement reached $-4.8 \mathrm{~mm}$ at the first cycle and $8.4 \mathrm{~mm}$ at the second cycle, respectively. At the second cycle of $3.0 \Delta_{y}$, the specimen made a rattling sound, which may be caused by the friction between connecting plate and bolt. When the displacement rose to $-22 \mathrm{~mm}$ at the first cycle of $5 \Delta_{y}$, concrete spalling was found around the right-top and right-bottom embedded parts; and the spalling lasted to the end of the loading procedure. At the second cycle of $7 \Delta_{y}$, local buckling of bottom flange near weld occurred when the displacement reached to $48 \mathrm{~mm}$, and with the displacement increased to $-67.2 \mathrm{~mm}$, accompanied by loud popping noises, the right weld fractured at the bottom flange. At this moment, severe concrete spalling was found around the embedded parts, moreover, many cracks appeared on the panel surface. Due to the experimental phenomenon, shown in Figure 6(a $\sim \mathrm{g})$, testing procedure was terminated.

The other seven specimens showed similar damaging progress, including appearance and propagation of cracks, spalling of concrete around the embedded parts, local buckling of beam flange, and weld fracture. It should be noted that weld fracture did not occur in Specimen 7; nevertheless bolt shearing was found when the displacement reached to $-43 \mathrm{~mm}$ at the first cycle of $5 \Delta_{y}$, which is shown in Figure 6(h).

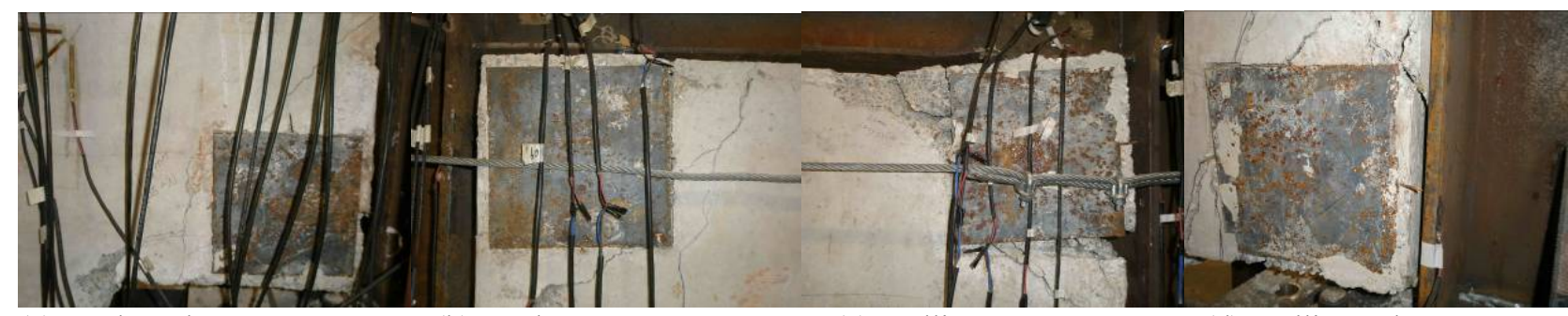

(a) cracks at bottom corner

(b) cracks at top corner

(c) spalling at top corner

(d) spalling at bottom corner

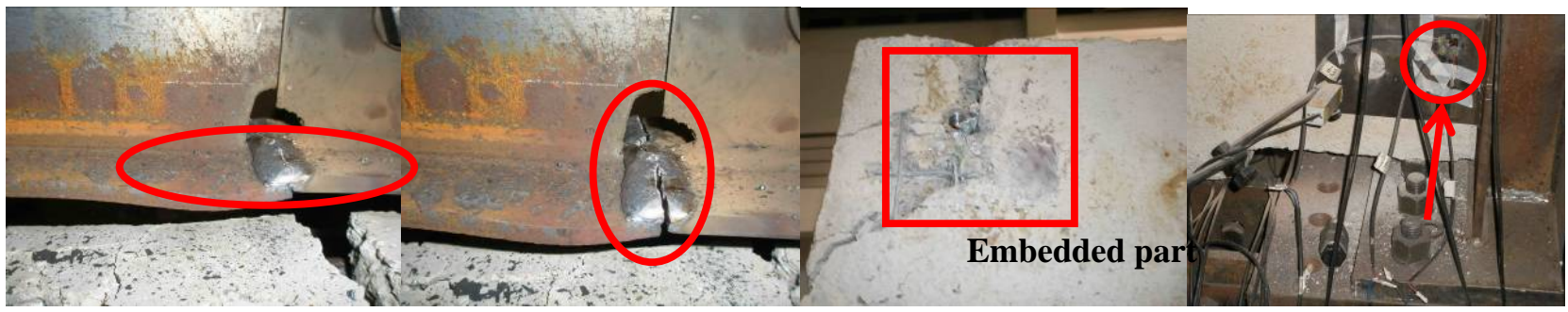

(e) local buckling

(f) weld fracture

(g) spalling

(h) bolt shearing

Figure 6. Failure Pattern of Specimen 
As can be seen from the experiment phenomenon, specimens tended to make rattling sound during the initial loading process, which attributed to the hole diameter $(40 \mathrm{~mm})$ of connecting plate was greater than that of bolt $(20 \mathrm{~mm})$. When the specimen was subjected to a horizontal load, the bolt slipped in the hole; however, the limited space $( \pm 10 \mathrm{~mm})$ restricted the relative slide between the connecting plate and bolt, hence interaction between panel and steel frame was achieved in state when the lateral displacement of specimen reached a high level. Now that mutual interaction was built, the steel frame resisted the load in cooperation with panel, so the initial lateral strength and initial lateral stiffness were raised, however, as to the quantitative analysis; the conducted experiment in this paper gives the results later. With the increasing of load, diagonal cracks around the embedded parts appeared on the surface of panel, and then long cracks were observed in the middle of panel. The observation was markedly different from the mentioned literatures, in which the infill panel, such as brick infill, masonry infill, and clay tile infill, generated large diagonal cracks across the panel. Therefore it shows that, as a precast concrete member, the composite panels exhibit a better integration than traditional walls. When the displacement increased from moderate level to high level, cracks around the embedded parts tend to dilate; namely cracks widen from cyclic loading along crack surfaces. As soon as cracks appeared, the forces transmitted from steel frame to panel were concentrated on the cracked region, followed by concrete spalling with the ongoing displacement. While for the rest part of panel, not only do no more new cracks appear, but also old cracks ceased to dilate. In the experiment, neither the connecting plate nor the embedded parts failed to keep working. These results showed that adequate detailing and proper construction of connection between steel frame and panel was achieved. It is important to note that the integral behavior of infilled frame depends on the success of connections of panels to the steel frames. S7, in which eight connecting plates were used, exhibited an obvious different behavior among all specimens. On the one hand, one of the bolts were sheared off during the loading process, which may be explained as: the infilled panel were so highly strengthened that the bolts which were allowed to slip slightly failed to resist the shearing force transmitted from the steel frame. On the other hand, the doubled bolts $(8 / 4=2)$ assured a much more effective cooperation between panel and steel frame, hence the panel made greater contribution to undertake the lateral force, consequently, neither the weld fractured nor the beam flange buckled.

\subsection{Lateral load (P) Versus Displacement Curves ( $\Delta$ )}

The $P$ - $\Delta$ hysteresis loops of the specimens are shown in Figure 7, in which $P$ is the load applied to the beam end and $\Delta$ is the corresponding displacement of the beam end. It is found that, in general, the hysteresis loops exhibit pinched behavior, which is quite typical for infills. The pinching behavior can be mainly explained by concrete spalling around the embedded parts. With an increase in beam end displacement, the lateral stiffness of specimen was observed to degrade. The stiffness degradation is attributed partly to plastic deformation of the steel frame but primarily to deactivation of panel. As mentioned previously, when the lateral displacement was so large that concrete spalling was found around the embedded parts, which led to the connection between panel and steel frame transmit mutual forces partially. Since the panel gradually quit working, the specimen shows a much lower lateral stiffness. By comparing S1 and S3, we find a thicker panel led to a fuller hysteresis loop, which means better energy dissipation ability. Meanwhile, a comparison is made between specimen 1 and specimen 4, the fuller hysteresis loop of specimen 1 gives the conclusion that column connection is more effective to integrate the steel frame and the infilled panel. 


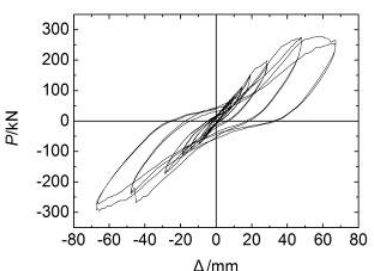

(a) S1

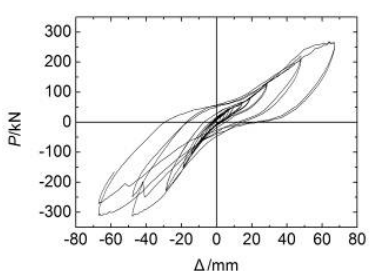

(e) S5

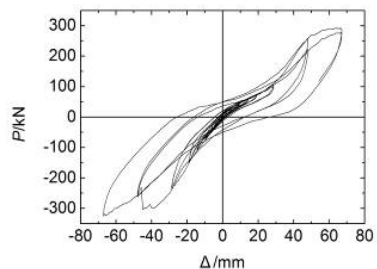

(b) S2

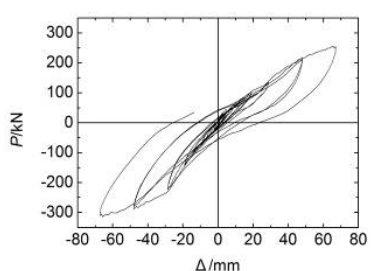

(f) $\mathrm{S} 6$

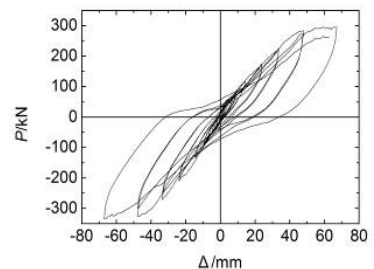

(c) S3

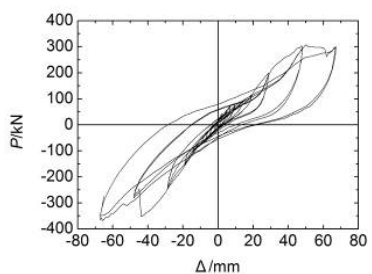

(g) S7

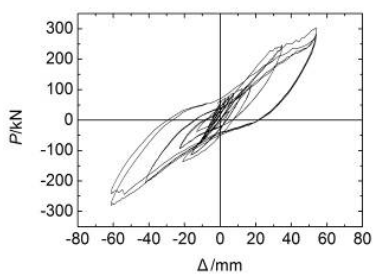

(d) S4

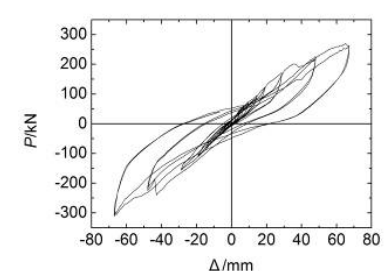

(h) S8

Figure 7. Load-displacement Hysteretic Loops

\subsection{P- $\Delta$ Envelope Curves}

According to the P- $\Delta$ hysteresis curves in Figure 7, the envelope curves, as illustrated in Figure 8 , are constructed by connecting the peak value in each loading cycle. The characteristic points of envelope curve are determined by using the given method in Figure 9, in which the ultimate load is defined as $P_{u}=0.85 P_{\max }$, and the corresponding displacement is $\Delta_{u}$, characteristic points of each specimen are listed in Table 3. In Figure 8, the envelope curves include two main portions. The positive loading portion shows no obvious degradation of the specimen strength, furthermore, the specimen strength even keep increasing till the end of experiment. It shows that although member damage occurred, such as weld fractured, beam bucked and concrete spalled, the specimen maintained bearing capacity, which were achieved by the success of connection between the frame and panel. As can be seen from Table 3, the ultimate displacement for each specimen is $48 \mathrm{~mm}$, and the yielding displacement is 5/12 5/8 of the ultimate displacement. One may conclude the following: (1) enhanced connection between the frame and the panel improved the maximum bearing capacity and ultimate capacity; (2) compared with infilled panel, out-hanged panel made few contributions to the lateral strength of the specimen, and the reduction is about $25 \%$.

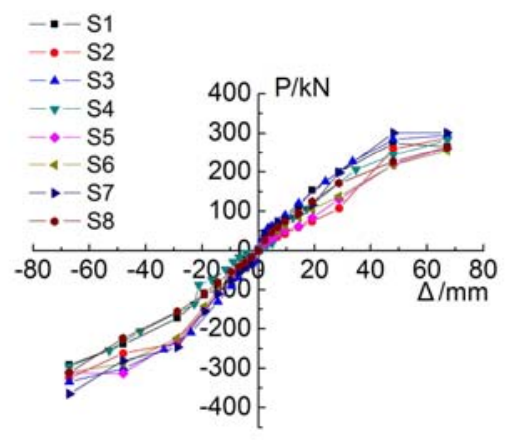

Figure 8. Skeleton Curves of Specimens

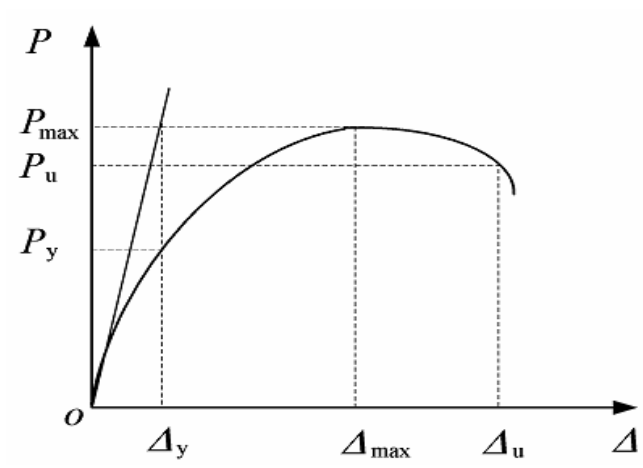

Figure 9. Determination of Feature Points 
Table 3. Characteristic Points of Skeleton Curves of Specimens

\begin{tabular}{ccccccc}
\hline & \multicolumn{2}{c}{ Yielding point } & \multicolumn{3}{c}{ Maximum point } & \multicolumn{2}{c}{ Ultimate point } \\
Specimen & $\Delta_{y}$ & $P_{y}$ & $\Delta_{\max }$ & $P_{\max }$ & $\Delta_{u}$ & $P_{u}$ \\
& $(\mathrm{~mm})$ & $(\mathrm{kN})$ & $(\mathrm{mm})$ & $(\mathrm{kN})$ & $(\mathrm{mm})$ & $(\mathrm{kN})$ \\
\hline S1 & 20.2 & 158.3 & 48 & 274.8 & 64.7 & 233.6 \\
S2 & 29.0 & 235.9 & 48 & 288.3 & 63.1 & 245.1 \\
S3 & 27.7 & 227.1 & 48 & 295.3 & 72.6 & 251.0 \\
S4 & 21.3 & 129.3 & 48 & 243.3 & 67.2 & 206.8 \\
S5 & 26.2 & 117.8 & 48 & 219.8 & 73.4 & 186.8 \\
S6 & 26.7 & 205.9 & 48 & 288.4 & 58.6 & 245.1 \\
S7 & 25.6 & 171.4 & 48 & 300.5 & 58.6 & 255.4 \\
S8 & 20.4 & 130.1 & 48 & 226.4 & 55.3 & 192.4 \\
\hline
\end{tabular}

\subsection{Strength Degradation}

The strength of test specimen degrades with increasing cycles of reverse loads. The characteristic of the strength degradation can be evaluated by the strength degradation coefficient $\left(\lambda_{j}\right)$ at the same load. The strength degradation coefficient at the same load is expressed as:

$$
\lambda_{j}=\frac{P_{j}^{i}}{P_{j}^{1}}
$$

Where $P_{j}^{i}$ and $\Delta / \Delta_{y}$ are respectively the maximum loads under the $i$ th and first loading cycles when the relative beam end displacement $\left(\Delta / \Delta_{y}\right)$ equals $\mathrm{j}$. The $\lambda_{j}-\Delta / \Delta_{y}$ relationship of the specimens is shown in Figure 10(a). In Figure 10(a), P and N respectively mean positive direction and negative direction respectively. We can obtain the conclusion that the strength degradation coefficient at the same load showed no obvious degradation trend.

In order to evaluate the total strength degradation characteristic of the specimens during the loading procedure, the strength degradation coefficient at the total loads $\left(\lambda_{i}\right)$ was introduced. The strength degradation coefficient at the total load is expressed as:

$\lambda_{i}=\frac{P_{i}}{P_{\max }}$

Where $P_{i}$ is the maximum load under the ith loading cycles when the relative beam end displacement $\left(\Delta / \Delta_{y}\right)$ equals $\mathrm{j}$; and $P_{\max }$ is the maximum load in the whole loading procedure. Figure 10(b) exhibits the $\lambda_{i}-\Delta / \Delta_{y}$ relationship of the specimens. The test results demonstrate that before the relative beam end displacement $\Delta / \Delta_{y} \leq 3, \lambda_{i}$ increases gradually with an increase of $\Delta / \Delta_{y}$; when $\Delta / \Delta_{y}>3, \lambda_{i}$ varies differently for each specimen with the increasing of the displacement, but the amplitude of variation is slight. This phenomenon shows that at the ultimate limit state the strength reduced slightly, namely the specimen still hold bearing capacity although the displacement was large. 


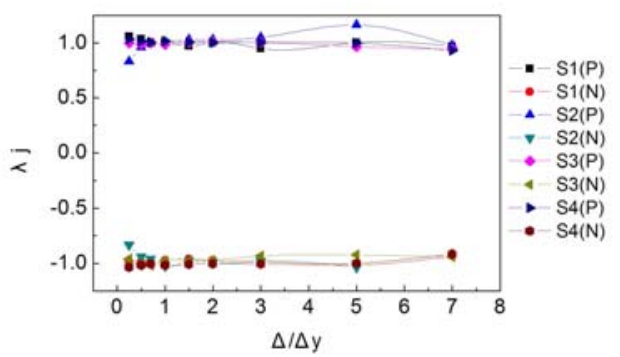

(a) Strength Degradation Curves at the Same Load(S1-S4)

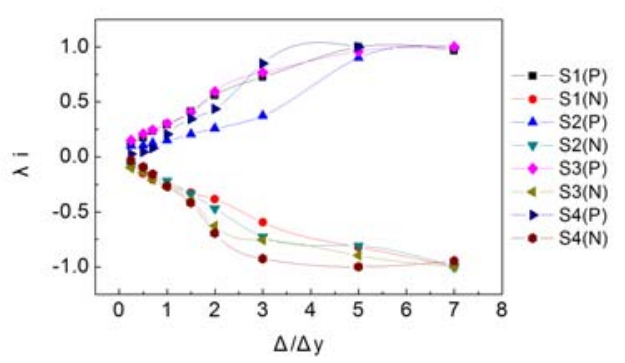

(c) Strength Degradation Curves at the Total Load(S1-S4)

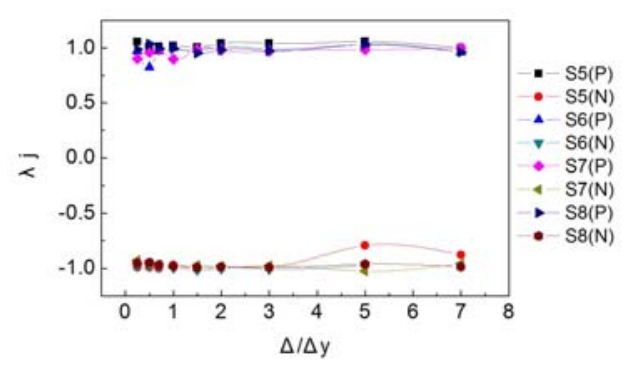

(b) Strength Degradation Curves at the Same Load(S5-S8)

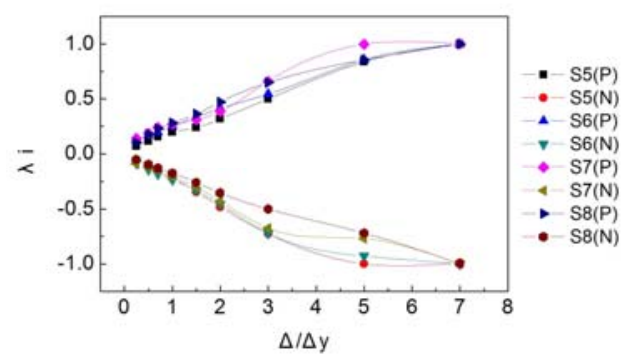

(d) Strength Degradation Curves at the Total Load(S5-S8)

Figure 10. Curves of Strength Degradation of the Specimens (P-positive, N-negative)

\subsection{Stiffness Degradation}

In order to reflect the stiffness degradation of specimens under cyclic loading, the stiffness of specimens can be evaluated by the index-cyclic stiffness (Tang [21]), which can be expressed as follows:

$$
K_{j}=\frac{\sum_{i=1}^{n} P_{j}^{i}}{\sum_{i=1}^{n} u_{j}^{i}}
$$

Where $K_{j}$ is cyclic stiffness, $P_{j}^{i}$ and $u_{j}^{i}$ are the maximum beam load and the corresponding displacement, respectively, under the ith loading cycle when the relative beam displacement $\left(\Delta / \Delta_{y}\right)$ equals $\mathrm{j}$, and $\mathrm{n}$ is the number of cycles when the deformation is controlled as $u_{j}$.

It can be concluded that the initial lateral stiffness of specimen ranged from $1.1 \times 10^{4} \mathrm{kN} / \mathrm{m}$ to $1.9 \times 10^{4} \mathrm{kN} / \mathrm{m}$. With a slight increasing of displacement, the lateral stiffness decreased sharply, and the drastic descending trend extended to the relative displacement $\Delta / \Delta_{y}=1$. At the following portion, $K_{j}$ decreased slowly and steadily, reached the final value of $4 \times 10^{3} \mathrm{kN} / \mathrm{m}$, which is about $1 / 4 \sim 1 / 3$ of the initial value. The following observation can be made by comparison: (1) the lateral stiffness can be enhanced by increasing the panel thickness and connection number; (2) the contribution of infilled panel is greater than out hanged panel; (3) the beam-to-column connection type of steel frame affected the lateral stiffness mildly. 


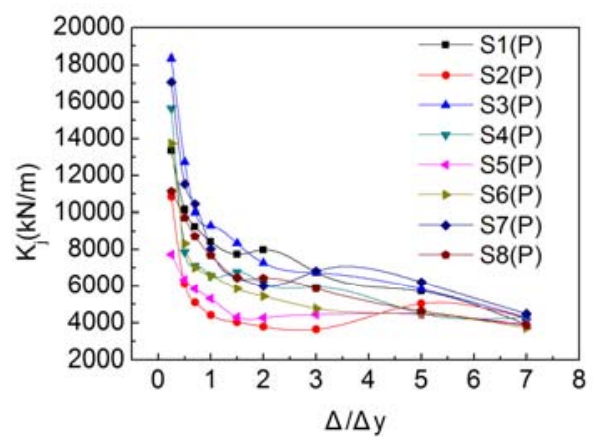

(a) Positive loading

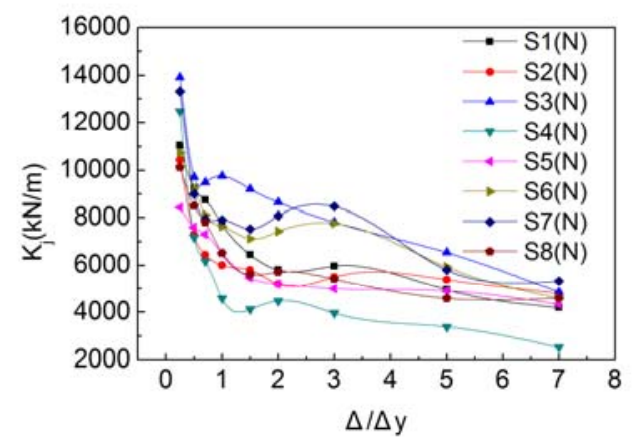

(b) Negative loading

Figure 11. Curves of Stiffness Degradation of the Specimens (P-positive N-negative)

\subsection{Ductility Coefficient}

In the seismic analysis of structural engineering, ductility is a pivotal parameter to take into consideration. In the present paper, the displacement ductility coefficient and angular ductility coefficient are used to take account of the ductility of the infilled steel frame subjected to seismic loading. The displacement ductility coefficient $\mu$ is defined as the ratio between the ultimate $\operatorname{displacement}\left(\Delta_{u}\right)$ and the yielding displacement $\left(\Delta_{y}\right)$, which can be expressed as $\mu=\Delta_{u} / \Delta_{y}$; The angular displacement ductility coefficient $\mu_{\theta}$ is defined as the ratio between the ultimate angular displacement $\left(\theta_{u}\right)$ and the yielding angular displacement $\left(\theta_{y}\right)$, which can be expressed as $\mu_{\theta}=\theta_{u} / \theta_{y}$, where $\theta_{u}=\arctan \left(\Delta_{u} / H\right), \theta_{y}=\arctan \left(\Delta_{y} / H\right), H$ is the column height and measured from the bottom to the center line of beam. Table 4 summarizes the displacement ductility coefficient and angular ductility coefficient of the test specimens. The Chinese Design Specification (GB50011-2010) [22] gives the detail ductility regulation for the moderate-high rise steel structures: the elastic layer angular displacement $\left[\theta_{e}\right]=1 / 300 \approx 0.0033 \mathrm{rad}=3.3 \mathrm{mrad}$, and the elastic-plastic layer angular $\left[\theta_{p}\right]=1 / 50=0.02 \mathrm{rad}$. From Table 4 , it can be found that the displacement ductility coefficient of the test specimens $\mu=2.18 \sim 3.20$, the elastic yielding angular ductility coefficient $\theta_{y}=2.53 \sim 3.63\left[\theta_{e}\right]$, and the elastic-plastic angular ductility coefficient $\theta_{u}=1.15 \sim 1.53\left[\theta_{p}\right]$. The comparison made between the test specimen and the steel structure can lead to the conclusion that the infilled steel frame exhibits excellent ductility and thus measure up to the requirement of the structural seismic design for Chinese Specification.

Table 4. Ductility Coefficient of Specimens

\begin{tabular}{ccccccc}
\hline Specimen & $\begin{array}{c}\text { Yielding } \\
\text { displacement }\end{array}$ & $\begin{array}{c}\text { Ultimate } \\
\text { displacement }\end{array}$ & $\begin{array}{c}\text { Yielding } \\
\text { angular } \\
\text { displacement } \\
\Delta_{y}(\mathrm{~mm})\end{array}$ & $\begin{array}{c}\text { Ultimate } \\
\text { angular } \\
\text { displacement } \\
\theta_{u}(\mathrm{~mm})\end{array}$ & $\begin{array}{c}\text { Displacement } \\
\text { ductility }\end{array}$ & $\begin{array}{c}\text { Angular } \\
\text { displacement } \\
\text { ductility }\end{array}$ \\
\hline 1 & 20.20 & 64.70 & 8.42 & 26.96 & 3.20 & 3.20 \\
2 & 29.00 & 63.10 & 12.08 & 26.29 & 2.18 & 2.18 \\
3 & 27.70 & 72.60 & 11.54 & 30.25 & 2.62 & 2.62 \\
4 & 21.30 & 67.20 & 8.88 & 28.00 & 3.15 & 3.15 \\
5 & 26.20 & 73.40 & 10.92 & 30.58 & 2.80 & 2.80 \\
6 & 26.70 & 58.60 & 11.13 & 24.42 & 2.19 & 2.19 \\
7 & 25.60 & 58.60 & 10.67 & 24.42 & 2.29 & 2.29 \\
8 & 20.40 & 55.30 & 8.50 & 23.04 & 2.71 & 2.71 \\
\hline
\end{tabular}




\subsection{Energy Dissipation Capacity}

The equivalent damping coefficient $\left(\xi_{e}\right)$ is adopted to analyze the energy dissipation capacity of the infilled steel frame. According to the simplified lateral load $(P)$-displacement $(\Delta)$ relationship shown in Figure 12, $\xi_{e}$ can be calculated by Eq. 4. In Figure 12, $\mathrm{S}_{\mathrm{ABC}}$ and $\mathrm{S}_{\mathrm{CDA}}$ are areas enclosed by curves $\mathrm{ABC}$ and $\mathrm{CDA}$, respectively, and $\mathrm{S}_{\mathrm{OBE}}$ and $\mathrm{S}_{\mathrm{ODF}}$ are areas within triangles $\mathrm{OBE}$ and $\mathrm{ODF}$, respectively.

$$
\xi_{e}=\frac{1}{2 \pi} \frac{S_{A B C}+S_{C D A}}{S_{O B E}+S_{O D F}}
$$

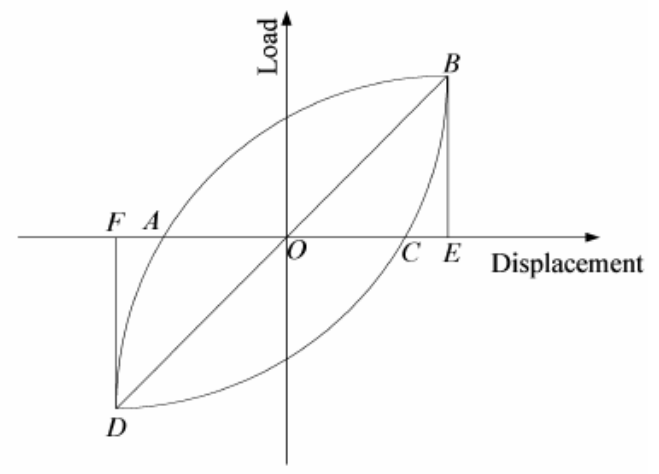

Figure 12. Determination for Energy Dissipated Coefficient

The dissipated energy capability $E$ of each hysteretic loop is also used to evaluate the energy dissipation capacity, and $E$ is expressed as:

$$
E=\frac{S_{A B C}+S_{C D A}}{S_{O B E}+S_{O D F}}=2 \pi \cdot \xi_{e}
$$

Figure 13 and Table 5 indicate that: (1) Generally, S3 and S7 exhibit better energy dissipation capacity than the other specimens, which confirms the conclusion that panel thickness and connection types are most influential factors to infilled frames; (2) The $\xi_{e}-\Delta / \Delta_{y}$ relationship includes two main portions. Initially, $\xi_{e}$ drops with increasing displacement, which is attributed to the dramatic decreasing of the lateral stiffness; however, in the second stage, when $\Delta / \Delta_{y} \geq 2, \xi_{e}$ increases with increasing displacement, which can be explained as: the severely damaged panel is gradually quitting action at this moment, and the curve reflects the plastic formation of steel frame. (3) At the yielding state, $\xi_{e}$ is between 0.04 and 0.1 ; at the maximum state, $\xi_{e}$ ranges from 0.12 to 0.14 ; at the final or ultimate state, $\xi_{e}$ is about $0.13 \sim 0.16$.

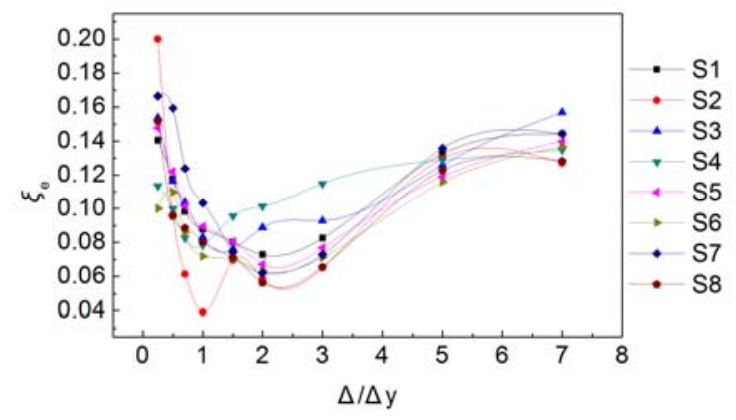

Figure 13. Relationship between $\xi_{e}$ and Displacement 
Table 5. Energy Dissipated Coefficients of Specimens

\begin{tabular}{|c|c|c|c|c|c|c|c|c|}
\hline Specimen & S1 & & S2 & & S3 & & $\mathrm{S} 4$ & \\
\hline Status & Max. & ultimate & $\max$. & ultimate & $\max$. & ultimate & $\max$. & ultimate \\
\hline Displacement $\Delta / \Delta_{y}$ & 5.0 & 7.0 & 5.0 & 7.0 & 5.0 & 8.0 & 5.0 & 7.0 \\
\hline $\begin{array}{l}\text { Total dissipated } \\
\text { energy }(N \cdot m)\end{array}$ & 10225 & 16984 & 9316 & 16402 & 11566 & 20853 & 9894 & 13638 \\
\hline $\begin{array}{l}\text { Equivalent } \\
\text { damping } \\
\text { coefficient } \xi_{e}\end{array}$ & 0.132 & 0.144 & 0.13 & 0.129 & 0.126 & 0.157 & 0.129 & 0.135 \\
\hline $\begin{array}{l}\text { Dissipated energy } \\
\text { capability } E\end{array}$ & 0.832 & 0.906 & 0.815 & 0.797 & 0.791 & 0.986 & 0.809 & 0.847 \\
\hline Specimen & S5 & & S6 & & S7 & & S8 & \\
\hline Status & Max. & ultimate & Max. & ultimate & Max. & ultimate & Max. & ultimate \\
\hline Displacement $\Delta / \Delta_{y}$ & 5.0 & 8.0 & 5.0 & 7.0 & 5.0 & 7.0 & 5.0 & 7.0 \\
\hline $\begin{array}{l}\text { Total dissipated } \\
\text { energy }(N \cdot m)\end{array}$ & 9338 & 16872 & 8717 & 16317 & 11765 & 20257 & 8193 & 15542 \\
\hline $\begin{array}{l}\text { Equivalent } \\
\text { damping } \\
\text { coefficient } \xi_{e}\end{array}$ & 0.119 & 0.14 & 0.116 & 0.137 & 0.136 & 0.144 & 0.123 & 0.128 \\
\hline $\begin{array}{l}\text { Dissipated energy } \\
\text { capability } E\end{array}$ & 0.748 & 0.878 & 0.727 & 0.859 & 0.853 & 0.906 & 0.771 & 0.804 \\
\hline
\end{tabular}

\section{CONCLUSIONS}

The following conclusions can be obtained from the observations and analysis on the conducted experiments of eight composite panels infilled steel frames:

(1) The main failure modes of composite panel infilled steel frames include the concrete spalling around the embedded parts, the local buckling of beam flange and weld fracture of beam. Compared with traditional panels and walls, composite panels in the present paper, as precast concrete members, exhibit a better integration.

(2) The integral behavior of infilled frame depends on the success of connections of panels to the steel frames. The connection type presented in the paper assured an effective connection between panels and frames.

(3) Both of increasing panel thickness and connection number enhances the lateral stiffness and lateral strength of the infilled frames, while panel position and beam-to-column connection type affect the infilled frame slightly. Generally, the initial lateral stiffness of infilled frames range from $1.1 \times 10^{4} \mathrm{kN} / \mathrm{m}$ to $1.9 \times 10^{4} \mathrm{kN} / \mathrm{m}$, and the final value is about $1 / 4 \sim 1 / 3$ of the initial value.

(4) The displacement ductility coefficient of the test specimens $\mu=2.18 \sim 3.20$, the elastic yielding angular ductility coefficient $\theta_{y}=2.53 \sim 3.63\left[\theta_{e}\right]$, and the elastic-plastic angular ductility coefficient $\theta_{u}=1.15 \sim 1.53\left[\theta_{p}\right]$. The comparison made between the test specimen and the steel structure can lead to the conclusion that the infilled steel frame exhibits excellent ductility and thus measure up to the requirement of the structural seismic design for Chinese Specification.

(5) At the yielding state, the equivalent damping coefficient $\xi_{e}$ is between 0.04 and 0.1 ; at the maximum state, $\xi_{e}$ ranges from 0.12 to 0.14 ; at the final or ultimate state, $\xi_{e}$ is about $0.13 \sim 0.16$. 


\section{ACKNOWLEDGEMEMT}

This paper was supported by the National Key Technology R\&D Program (Grant No. 2006BAJ04A02-06), Shandong Provincial Natural Science Foundation, China (Grant No. ZR2011EEM023), China Postdoctoral Science Foundation funded project (Grant No. 20090450736), Shanghai Postdoctoral Sustentation Fund (Grant No. 09R21415800) and Shandong Postdoctoral Science Foundation (Grant No. 200902004).

\section{REFERENCES}

[1] Polyakov, S.V., "On the Interaction between Masonry Filler Walls and Enclosing Frame when Loaded in the Plane of the Wall", Translations in Earthquake Engineering, Earthquake Engineering Research Institute, San Francisco, 1960, pp. 36-42.

[2] Polyakov, S.V., "Masonry in Framed Buildings", G.L. Cairns, Translator, National Lending Library for Science and Technology, Boston Spa, Yorkshire, U.K., 1963.

[3] Papia, M., Cavaleri, L. and Fossetti, M., "Infilled Frames: Developments in the Evaluation of the Stiffening Effects of Infills", Structural Engineering and Mechanics, 2003, Vol. 16, No. 6, pp. 675-693.

[4] Cavaleri, L., Fossetti, M. and Papia, M., "Infilled Frames: Developments in the Evaluation of Cyclic Behaviour under Lateral Load”, Structural Engineering and Mechanics, 2005, Vol. 21, No. 4, pp. 469-494.

[5] Holmes, H., "Steel Frames with Brickwork and Concrete Infilling", Proceeding of Institution of Civil Engineers, 1961, pp. 473-478.

[6] Mosalam, Khalid M., White, Richard N. and Gergely, Peter, "Static Response of Infilled Frames Using Quasi-static Experimentation”, Journal of Structural Engineering, 1997, Vol. 123, No. 11, pp. 1462-1469.

[7] Kwan, K.H. and Liauw, T.C., "Nonlinear Analysis of Integral Infilled Frames", Engineering Structure, 1984, Vol. 6, pp. 223-231.

[8] Liauw, T.C. and Kwan, K.H., "Nonlinear Behavior of Non-integral Infilled Frames", Comput. \& Structures, 1984, Vol. 18, No. 3, pp. 551-560.

[9] Moghadam, H.A., "Seismic Behavior of Infilled Frames", Ph.D. Thesis, Imperial College, University of London, 1988.

[10] Moghadam, H.A., Mohammadi, M.Gh. and Ghaemian, M., "Experimental and Analytical Investigation into Crack Strength Determination of Infilled Steel Frames", Journal of Constructional Steel Research, 2006, Vol. 62, No. 12, pp. 1341-1352.

[11] Moghadam, H.A., "Lateral Load Behavior of Masonry Infilled Steel Frames with Repair and Retrofit", Journal of structural engineering, 2004, Vol. 130, No. 1,pp. 55-63.

[12] Moghadam, H.A., and Mahmoodi, A., "Seismic Strengthening of Masonry Infilled Structures", Proceedings of the 10th European Conference on Earthquake Engineering, 1994, pp. 2293-7.

[13] Mohammadi, M. and Moghadam, H.A., "Mathematical Functions to Evaluate Stress of Infilled Frames", Proceedings of the 1st Iranian National Conference of Civil Engineering, 2004.

[14] Mohebkhah, Amin, Tasnimi, A.A. and Moghadam, H.A., "Nonlinear Analysis of Masonry-infilled Steel Frames with Opening using Discrete Element Method", Journal of Constructional Steel Research, 2008, Vol. 64, No. 12 ,pp. 1463-1472.

[15] Saari, William K.. Hajjar, Jerome F., Schultz, Arturo E. and Shield, Carol K., "Behavior of Shear Studs in Steel Frames with Reinforced Concrete Infill Walls", Journal of Constructional Steel Research, 2004, Vol. 60, No. 10 ,pp. 1453-1480. 
[16] Tong, X.D., Hajjar, Jerome F., Schultz, Arturo E. and Shield, Carol K., "Cyclic Behavior of Steel Frame Structures with Composite Reinforced Concrete Infill Walls and Partially-restrained Connections", Journal of Constructional Steel Research, 2005, Vol. 61, No. 4 , pp. 531-552.

[17] Wright, H.D. and Gallocher, S.C., "The Behavior of Composite Walling under Construction and Service Loading", Journal of Constructional Steel Research, 1995, Vol. 35, No. 3, pp. 257-273.

[18] Hanaor, Ariel., "Experimental Investigation of Composite Shear Panels under Cyclic Loading”, Journal of Constructional Steel Research, 2005, Vol. 61, No. 3, pp. 345-369.

[19] De Matteis, Gianfranco, Landolfo, Raffaele, "Modelling of Lightweight Sandwich Shear Diaphragms for Dynamic Analyses", Journal of Constructional Steel Research, 2000, Vol. 53, No. 1, pp. 33-61.

[20] ATC-24, "Guidelines for Cyclic Seismic Testing of Components of Steel Structures", Redwood City (CA): Applied Technology Council, 1992.

[21] Tang, J.R., "Seismic Resistance of Joints in Reinforced Concrete Frames", Nanjing (China): Southeast University Press, 1989.

[22] GB50011-2010, "Specification of Structural Seismic Design”, Beijing, China Building Industry Press, 2010. [in Chinese] 